\title{
TACKLING INTERNATIONAL AIRLINE CATERING WASTE MANAGEMENT: LIFE ZERO CABIN WASTE PROJECT. STATE OF THE ART AND FIRST STEPS
}

\author{
Gonzalo Blanca-Alcubilla ${ }^{1}$, Alba Bala ${ }^{1}$, Juan Ignacio Hermira ${ }^{2}$, Nieves De-Castro ${ }^{3}$, Rosa \\ Chavarri ${ }^{4}$, Rubén Perales ${ }^{5}$, Iván Barredo ${ }^{6}$ and Pere Fullana-i-Palmer *,1 \\ 1 UNESCO, Chair in Life Cycle and Climate Change ESCI-UPF, Universitat Pompeu Fabra, Passeig Pujades 1, 08003 Barcelona, Spain \\ 2 IBERIA, Calle Martínez Villergas, 49, 28027 Madrid, Spain \\ ${ }^{3}$ GATE GOURMET, Carretera de la Muñoza, 28042 Madrid, Spain \\ ${ }^{4}$ ECOEMBES, Paseo de la Castellana, 83 - 85, 28046 Madrid, Spain \\ ${ }^{5}$ FERROVIAL, C/ Uranio, 18, 28946 Fuenlabrada, Spain \\ ${ }^{6}$ BIOGAS FUEL \& CELL, Calle Ada Byron, no 107, 33203 Gijón, Asturias, Spain
}

Article Info:

Received:

22 February 2018

Revised:

29 June 2018

Accepted:

6 August 2018

Available online:

10 September 2018

Keywords:

LCA

Food waste

Catering

Airplane

Carbon footprint

\section{ABSTRACT}

Concerns about cabin waste date back more than two decades. However, in the past few years, several airlines and stakeholders (notably catering companies) have increased their efforts to tackle this issue. A number of factors such as low landfill disposal rates, particularly for inorganic fractions, lack of appropriate facilities and restrictive regulations had traditionally discouraged airlines and other actors to proactively look for solutions. LIFE+ Zero Cabin Waste aims to create a sustainable model to reduce, re-use and recycle (including energy recovery) waste recollected in Iberia airplane cabins in Madrid-Barajas Airport (Spain) and set the basis for its replication by other airlines and related stakeholders in the future. The objectives of this project are: properly separate the cabin waste on board, demonstrate that waste can be dealt with in a more environmentally friendly way contributing to the reduction of the high carbon footprint associated to the generation and the current inadequate management of cabin waste and set the basis for replication through standard protocols. The project, although it is in the first stage, has already been laid the bases and recommendations for future implementations and improvements that will allow reaching the proposed objectives.

\section{INTRODUCTION}

Waste produced in aircrafts is far from minor. According to Godson (2014), passengers worldwide produce an average of $1.43 \mathrm{~kg}$ of waste per trip. On the basis of the above data and the latest report of the Airports Council International $(\mathrm{ACl})$, which states that there were about 7.7 billion plane passengers worldwide in 2016 ( $\mathrm{ACl}, 2017)$, we can estimate a production of about 11 billion $\mathrm{kg}$ of waste produced by aircraft passengers per year.

Concerns about cabin waste date back more than two decades where characterizations of this waste stream started to be analyzed so as to highlight the hot spots and develop recycling strategies ( $\mathrm{Li}$ et al. 2003). Despite this early concern, until now most airlines and catering companies have been recycling very little and the waste obtained is typically of low quality due to the mix of multiple waste fractions. A number of factors such as low landfill disposal rates (particularly for inorganic fractions), lack of appro- priate facilities and restrictive regulations had traditionally discouraged airlines and other actors to proactively look for solutions.

However, in the last years, a change of trend can be observed. After thorough research made by the authors of this paper, it can be stated that several airlines and stakeholders (notably catering companies) have increased their efforts to tackle this issue. This is the case of Ryanair, for instance, that have promised to eliminate non-recyclable plastics from its operations by 2023. In addition to switching to biodegradable cups, wooden cutlery and paper packaging onboard, Ryanair said it would make its head offices, bases and operations plastic free (Topham, 2018). British Airways expect to decrease the amount of waste that goes to landfill and recycle $50 \%$ of waste by 2020 (British Airways, 2018). Other companies such as Alaska Airways are committed to reducing the waste from all paper, cups, bottles and cans on every domestic flight they operate (Alaska 
Airways, 2015). At this point is worth to mention that all these efforts made by aircraft operators are usually single initiatives, lacking a comprehensive and holistic approach. Nevertheless, an increasing public environmental consciousness that scrutinizes companies' behaviors as well as the progressive price increase in disposal rates are triggering more responsible solutions to this problem.

The management of catering waste is regulated both by the Waste Directive (Official Journal of the European Union, 2008) and the Packaging and Packaging Waste Directive (EC Packaging Waste Directive, 1994) since waste from meals and the packaging of those meals is produced due to the catering service and treated jointly. These two directives follow the inverted waste hierarchy pyramid).

\subsection{Classification of Cabin Waste}

When discussing cabin waste, it is necessary to make a preliminary clarification and distinguish between two different types of waste categories depending on its origin, namely category 1 (Cat1) and 3 (Cat3), even if, technically, both categories belong to the management of animal by-products, the so-called SANDACH waste (animal by-products not intended for human consumption) (European Parliament, 2009).

International catering waste (ICW) is not considered risky waste when the planes are traveling in EU territory only, and it is classified as Cat3. However, in flights from countries not included in EU territory, ICW is considered as animal by-product and, therefore, included in high-risk classified as Cat1. It is assumed that a potential risk of the spread of animal diseases exists, being dangerous to animal and human health if not properly disposed of. The European Parliament regulates the way in which ICW can be disposed of. Waste classified as Cat 1 must be disposed of by burial in an authorized landfill according to the EU 1069/2009 Regulation (European Parliament, 2009).

\subsection{Current treatment of Cabin Waste}

In Madrid-Barajas Airport, such as the rest of Spanish airports, waste from flights from destinations within the EU (classified as Cat3) is formed by a mix of inorganic recoverables (light packaging plastics, cans, cartons, glass and paper) and what is assimilated to and called MSW (Municipal Solid Waste) fraction. This last is mainly composed of organic matter plus all other waste that the crew cannot separate (typically napkins, thin plastics, etc.). In the case of Iberia flights, as well as in other airline operators from Madrid-Barajas Airport, all those fractions are mixed in the same bag and accumulated in containers, which the authorized waste manager collects and brings to a sorting plant. There the inorganic recoverable materials are separated to be sent to a recycler. For the case of flights coming from outside the EU (classified as Cat1) this waste is collected in bags that are stored in containers that will be collected by the same management company, but unlike Cat3 waste, it is not sent to a sorting plant: it is directly deposited in an authorized landfill. (Figure 1).

Landfilling is a cheap way to dispose of waste, but very expensive if we take into account its environmental implications. Estimations speak of global $\mathrm{CH}_{4}$ emissions from landfills to be 500-800 $\mathrm{Mt} \mathrm{CO}$-eq/y (Bogner et al., 2007). Only regarding food waste, $1.9 \mathrm{t} \mathrm{CO}_{2}$-eq. (at least) are emitted per tonne of food waste, which amounts $170 \mathrm{Mt}$ of $\mathrm{CO}_{2}$ eq. (at least) emitted per year, representing $\sim 3 \%$ of total EU27 GHG emissions (Bio Intelligence Service, 2010). In our project case, of the 6,000t, a third of the tons are Cat3, of which $40 \%$ (according to preliminary characterizations results) of the waste is organic matter. In addition, of the
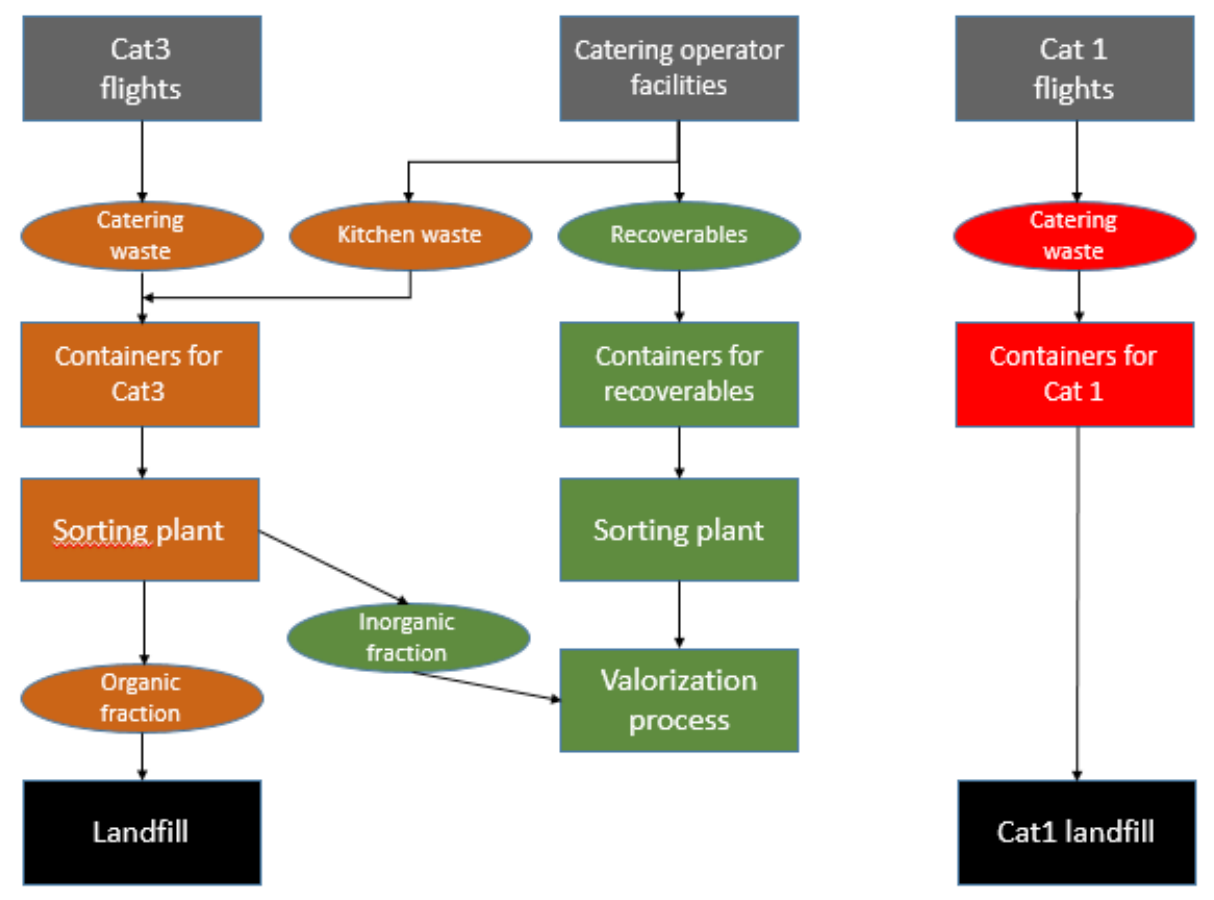

FIGURE 1: Current waste management for Cat3 and Cat1 waste. 
4,000 t that are generated from Cat $1,52 \%$ are organic matter, so that it ends up in landfill 2,880t annually. This translates, according to the emission factors for food waste previously shown, into $5,472 \mathrm{t} \mathrm{CO}_{2}$-eq per year.

\section{ZERO CABIN WASTE PROJECT}

ZERO CABIN WASTE is a project founded by the Life Programme of the EU. It started in 2017 and is supposed to finalize in 2019. Table 1 shows the partners and their roles in the project.

\subsection{Objectives}

The project aims to create a sustainable model to reduce, re-use and recycle (including energy recovery) waste recollected in Iberia airplane cabins in Madrid-Barajas Airport (Spain) and set the basis for its replication in the future by other airlines and related stakeholders. Its final objective is to drastically reduce landfilling with at least $80 \%$, (50\% through recycling and 30\% through energy recovery and compost), considering both Cat 1 and Cat3 residues.

The specific objectives of the project are listed below:

- Paying more attention to the management of cabin waste. In order to reduce the amount of waste and to obtain more homogeneous waste streams that facilitate its subsequent recovery, a better classification at source is important. In this area, waste minimization must also be achieved through the implementation of good practices and eco-design measures for the menus served on board. Those measures require the involvement and the efficient coordination of all the agents involved;

- Change the legislation on the treatment of this type of waste has to follow. Currently, European legislation states that international cabin waste of animal origin must be incinerated or deposited in authorized landfills. The project aims to demonstrate that the current law is to some extent antiquated, overprotective and wasteful. By means of a sterilization treatment of Cat1, hazardous substances can be eliminated and, therefore, this type of waste can be valorized like Cat3 waste;

- Reduce the carbon footprint of the current waste management system. Landfill is the end of life option that emits more GHG (Cherubini et al. 2009). The project aims to reduce the amount of (mainly organic) waste sent to a landfill, and therefore, a reduction in GHG emissions is foreseen. The total reduction will be measured through a life cycle assessment (LCA) comparing the current management system with the proposed new system;

- Allow the replication of the new waste management system by other airlines and catering services to contribute to the reduction of the carbon footprint of its activities. This project is intended to demonstrate that with a comprehensive approach and a solid partnership between the members of the system, the waste management system can be improved.

\subsection{Action plan}

To achieve the objectives described above, the action plan is organized in the following stages:

- Preparatory actions. Detailed inventory of the waste flows and fractions per type of flight; analysis of potential re-use and waste minimization opportunities; consultations with key stakeholders and design of the recycling process. Current practices (processes, flows and fractions) modeled in an LCA program;

- Implementation actions. Training of crew and staff; installation of equipment adjustments; execution of the collection and separation protocol; processing of waste fractions; implementation of a pilot treatment for Cat. 1 waste; and partial replication of the actions at Heathrow Airport;

- Monitoring of Technical and Environmental Progress. Technical monitoring of performance indicators (also LCA); proposed practices (processes, flows and fractions) modeled in an LCA program. At the end of the project, conclusions and recommendations will be given, including the socio-economic impact report of the project;

- Public awareness and dissemination of results. The project website and social media will be used in order to engage not only the passengers on board but also the professional stakeholders at national and EU level. Reforestation events will engage employees and clients further;

- Finally, project management will be carried out by all

TABLE 1: Partnership and project roles.

\begin{tabular}{|c|c|}
\hline Partner & Role in the project \\
\hline IBERIA & $\begin{array}{l}\text { Coordinator \& General project management. Leader in several preliminary and implementation actions and dissem- } \\
\text { ination activities. Separation of waste onboard. }\end{array}$ \\
\hline GATE GOURMET & $\begin{array}{l}\text { Caterer of Iberia. First receptor of offloaded waste and responsible for first controls and further waste management. } \\
\text { Leader of several preliminary and implementation actions. Contribute to technical monitoring and dissemination. }\end{array}$ \\
\hline ECOEMBES & $\begin{array}{l}\text { Responsible for sub actions concerning mainly waste characterizations, trainings and awareness-raising materials. } \\
\text { Also in charge of conclusions and recommendations. Contribute to technical monitoring and dissemination. }\end{array}$ \\
\hline BIOGAS FUEL CELL & $\begin{array}{l}\text { Involved in several actions concerning waste management opportunities and design. Responsible for pilot action B5 } \\
\text { (treatment of organic fraction Cat. } 1 \text { waste). Contribute to technical monitoring and dissemination. }\end{array}$ \\
\hline FERROVIAL & $\begin{array}{l}\text { Mainly responsible for the management of waste in recycling plant and valorization process. Contribute to technical } \\
\text { monitoring and dissemination. }\end{array}$ \\
\hline ESCI-UPF & $\begin{array}{l}\text { Involved in different actions and sub-actions as to monitor LCA related parameters. Responsible for developing a } \\
\text { state of the art LCA for aviation industry and for compiling and monitoring project performance indicators. }\end{array}$ \\
\hline
\end{tabular}


partners. Project evaluation and auditing will be part of this action, as well as the after-Life communication plan.

\subsection{Project innovation}

Given the nature of this project, its innovations are more related to conceptual, organizational and methodological aspects, rather than to strictly technological developments. It is also worth mentioning the scale of the implementation. Companies such as Delta Airlines already recycle aluminum cans, plastic bottles, plastic trays, beverage cups, newspapers, and magazines but they only do it in a small percentage of flights operated (around 8\%) and just in one international destination. This project deals with waste produced in aircrafts as a whole, looking for an integrated solution based on prevention, preparation for re-use and recycling. It also brings on board all main stakeholders involved along the whole chain and considers the impact through the life-cycle of the activities. This is a major difference in comparison to other strategies initiated by other airline companies.

It is intended to implement the actions at full scale with IBERIA's flights, both at EU and international level, having trained all members of its crew as well as Gate Gourmet's staff in Madrid and at Heathrow. Thus, creating a best practice code with a very high replication potential. To replicate, the geographical factor should be taken into account. The airlines and related companies' possibilities differ from one continent to another significantly. For example, some Asian airlines already introduce in the contracts of their crews the obligation to separate on board. We are far from this point in Europe, where cooperation of the crew remains a challenge and must be tackled tactfully and realistically. Another important difference is that, on other continents, airlines and authorities are more open to tackle the issue of Cat1 waste. This is the case of, for example, Australia or Canada, where sterilization of this kind of waste has already been successfully trialed. Consequently, the project must be understood in a European context (same legislation and culture), even if its expected outcomes could be replicated elsewhere worldwide.

The proposal of an alternative method to manage Cat1 waste which does not exist in Europe sets the highlight in the innovation of this project. At an early stage, it is foreseen to treat a small fraction of Cat1 with different methods to prove it innocuous for human and animal health, then taking the organic fraction to a bio digestion process allowing energy recovery. Afterward, the proposed management system (Figure 2) will be scaled for the treatment of Cat1 waste to industrial levels and its environmental performance will be measured trough an LCA. Implementing this integrated waste management system in which separate collection in origin takes place, with energy recovery from waste and reducing landfill disposal can guarantee high efficiency when minimizing CO2eq emissions (Calabrò, 2009), (Calabrò, Gori, \& Lubello, 2015).

Although European legislation allows both incineration and landfilling as a way to manage Cat1 waste, Spanish legislation has narrowed down options to disposal in landfill. As one of the main objectives of this project is to reduce the carbon footprint of the system, bio digestion is a better option for the energy recovery of Cat1 organic matter rather than incineration as an alternative to landfilling (Eriksson et al., 2015).

Finally, in collaboration with national \& EU relevant authorities, it is intended to develop an integrated best practice guideline on catering waste management that would include the new proposed valorization method.

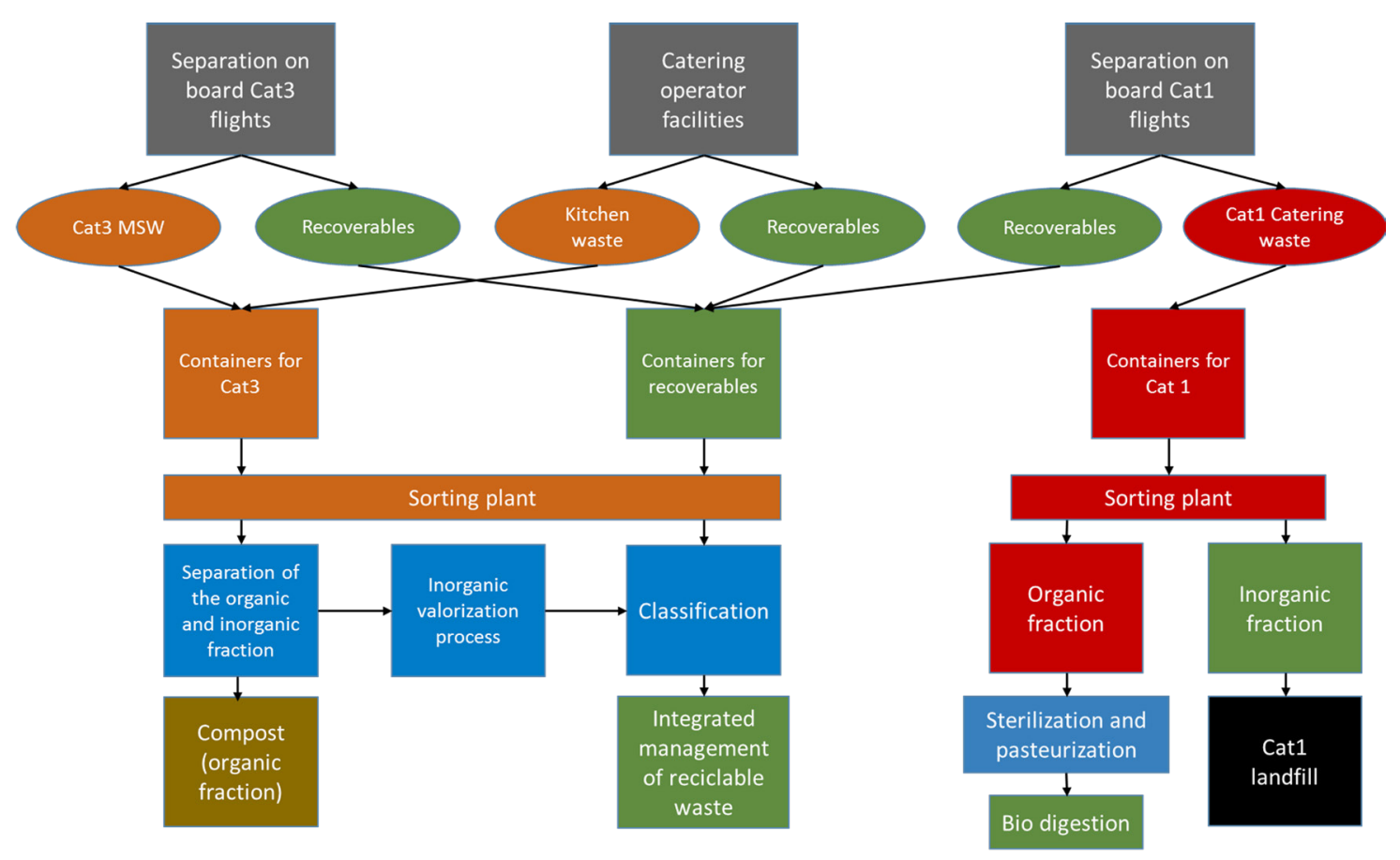

FIGURE 2: Future waste management for Cat3 and Cat1 waste. 


\section{DISCUSSION AND FIRST OUTCOMES OF ENVIRONMENTAL PERFORMANCE}

Thorough bibliography research of LCA studies dealing with catering and aviation was performed. The use phase was found to have the greatest environmental impact, due to the kerosene burned during the flights (Horvath and Chester, 2008) (Lopes, 2010) (Howe, Kolios, \& Brennan, 2013). To deal with this, the literature proposes that the impact can be reduced by making parts of the aircraft from lighter materials that would save fuel (Timmis et al., 2015). Although the manufacture of these components (carbon fiber) has a greater impact than traditional materials, (aluminum), it is largely offset by the reduction of impact during the aircraft use phase, by reducing weight (Beck et al. 2011).

However, no specific references for catering in aviation were found, although the same option of weight reduction may apply. Finally, the research was expanded to also englobe LCA studies on food and packaging in other sectors, in order to learn from eco-design alternatives other than dematerialization.

Regarding food, it was found that from the stage of agriculture until reaching the final consumer, the stage of agriculture is the one with the greatest environmental impact (Bellarby et al. 2008), followed by transportation and manufacturing (Tassielli et al. 2017). It will be crucial to take into account its origin so that, according to their associated environmental impact, increasing the design of menus with lower carbon footprint (Sim et al. 2007). The types of food that contribute most to the impact categories are those of animal origin, especially those of bovine origin (Foster et al. 2007) (Williams et al. 2006). Indeed, food of vegetable origin is the one with the least impact.

With regard to catering, comparative studies have been published between reusable and non-reusable packaging for glasses, plates and cutlery. The manufacture of reus- ables produces more impact than those of a single use, but it can be offset by the number of uses that the reusable ones can be given by a single container (Garrido and Alvarez del Castillo, 2007). Therefore, the number of uses together with the efficiency of the washing process, which is the stage with the greatest impact on the life cycle of the reusable containers and cutlery, will determine whether it is more beneficial to use disposable or non-disposable ones (Woods and Bakshi, 2014) (Pro.mo/Unionplast, 2009).

Due to the fact that the possible and alternative treatment of cabin waste depends largely on its composition, a characterization of the waste generated in the aircraft was done. Residues of 87 different flights were analyzed. As on some flights there is not enough waste generation to make a characterization, those flights were grouped as shown in Table 2.

As can be seen in the previous figure, flights coming from London and Medium flights that were longer than average, enough waste was generated to make characterizations out of a single airplane.

Flights were differentiated according to the length of the flight: National (flights coming from Spain), European, (those coming from EU), and International (being Short, Medium or Long depending if the flight takes more than 3, 5 or 7 hours, respectively).

Waste streams were also taken into account differentiating 5 streams as showed in Table 3.

Waste was differentiated by material and was subgrouped by the type of plastic and metal and whether it had been manipulated (the packaging, has been opened no mater if the content was consumed or not) or unmanipulated (Table 4).

The latter was important, since packaging manipulated on board is considered waste regardless its final consumption by the passenger or not. Now the composition and the amount of waste generated during every single Iberia's flight is known, as well as the generation of waste per pas-

TABLE 2: Grouping of flights for waste characterization.

\begin{tabular}{|c|c|c|c|}
\hline Type of flight & Number of flights grouped & Number of groups & Total flights \\
\hline National & 5 & 5 & 25 \\
\hline $\begin{array}{l}\text { European } \\
\text { (Flights from London) }\end{array}$ & $\begin{array}{l}4 \\
1\end{array}$ & $\begin{array}{l}7 \\
3\end{array}$ & 31 \\
\hline Short International & 2 & 1 & 2 \\
\hline $\begin{array}{l}\text { Medium International } \\
\text { Longer flights }\end{array}$ & $\begin{array}{l}2 \\
1\end{array}$ & $\begin{array}{l}2 \\
3\end{array}$ & 7 \\
\hline Long International & 1 & 22 & 22 \\
\hline & & & 87 \\
\hline
\end{tabular}

TABLE 3: Different waste streams.

\begin{tabular}{l|l}
\hline Stream & Description \\
\hline Waste trolley & They contain waste generated during the flight, mainly coming from the sale on board \\
\hdashline Galley & Trolleys that mainly contain baverages (water, soft drinks, wines, juices) and napkins \\
\hdashline Business menu & Trolleys that contains the remains of the menus that have been served (trays) \\
\hline Tourist menu & Trolleys that contain the remains of the 2 nd menus that have been served \\
\hline 2nd menu & T.u. \\
\hline
\end{tabular}




\begin{tabular}{|c|c|c|c|c|c|c|c|c|c|c|}
\hline \multicolumn{8}{|c|}{ Manipulated } & \multicolumn{3}{|c|}{ Unmanipulated } \\
\hline Packaging & $\begin{array}{c}\text { Organic } \\
\text { matter }\end{array}$ & Cellulose & Cutlery & Glass & $\begin{array}{l}\text { Paper and } \\
\text { cardboard }\end{array}$ & $\begin{array}{c}\text { Organic } \\
\text { Matter in } \\
\text { packaging }\end{array}$ & $\begin{array}{l}\text { Liquid in } \\
\text { packaging }\end{array}$ & Packaging & $\begin{array}{l}\text { Organic } \\
\text { Matter }\end{array}$ & $\begin{array}{l}\text { Liquid in } \\
\text { packaging }\end{array}$ \\
\hline PET & $\begin{array}{l}\text { Natural } \\
\text { HDPE }\end{array}$ & $\begin{array}{l}\text { Color } \\
\text { HDPE }\end{array}$ & Film & PP & PS & $\begin{array}{l}\text { Other } \\
\text { Plastics }\end{array}$ & Alumin & Flexi & $\begin{array}{l}\text { olylamir } \\
\text { kaging }\end{array}$ & Wood \\
\hline
\end{tabular}

senger since information about the number of passengers of each airplane studied was gathered. Another article is being done with the whole study and analysis of the characterizations. Table 5 shows the waste generation per passenger depending on the flight length.

For National, European and Short International flights, most of the waste is collected in the waste trolley flow (64\%) as, on these flights, no tourist class menu is served, therefore there is no tourist trolley on board. Followed by the business menu flow (31\%) and the galley (5\%). As for Long International flights and Medium International flights, the majority of the waste comes from the tourist flow $(29 \%)$, followed by the waste flow $(22 \%)$, business menu (21\%), second tourist menu (15\%) and galley (13\%) (Table 6).

With the outcomes of all this research, an eco-design guideline for the catering services company (GG) was developed, including recommendations for changes in the configuration of the menus (reducing the amount of meat) changes in the design of some packaging items (extending the use of reusable solutions) and also other recommendations to reduce the amount of generated waste in each flight (such us asking passenger preferences when book-

TABLE 5: Waste generation per passenger and flight.

\begin{tabular}{l|c} 
Flight & Kg/passenger \\
\hline National & 0,14 \\
\hline European & 0,25 \\
\hline Short International & 0,23 \\
\hdashline Medium International & 0,99 \\
\hline Long International & 1,4 \\
\hline
\end{tabular}

TABLE 6: Waste generation streams.

\begin{tabular}{|c|c|c|}
\hline Type of flight & Sources & $\%$ waste \\
\hline National & $\begin{array}{c}\text { Galley } \\
\text { Waste Trolley } \\
\text { Business }\end{array}$ & $\begin{array}{c}8 \% \\
61 \% \\
31 \%\end{array}$ \\
\hline European & $\begin{array}{c}\text { Galley } \\
\text { Waste Trolley } \\
\text { Business }\end{array}$ & $\begin{array}{l}5 \% \\
63 \% \\
32 \%\end{array}$ \\
\hline Short International & $\begin{array}{c}\text { Waste Trolley } \\
\text { Business }\end{array}$ & $\begin{array}{l}70 \% \\
30 \%\end{array}$ \\
\hline Medium International & $\begin{array}{c}\text { Galley } \\
\text { Waste Trolley } \\
\text { Business } \\
\text { Tourist }\end{array}$ & $\begin{array}{c}6 \% \\
34 \% \\
21 \% \\
39 \% \\
\end{array}$ \\
\hline Long International & $\begin{array}{c}\text { Galley } \\
\text { Waste Trolley } \\
\text { Business } \\
\text { Tourist } \\
\text { 2nd menu }\end{array}$ & \begin{tabular}{l|}
$13 \%$ \\
$20 \%$ \\
$21 \%$ \\
$27 \%$ \\
$19 \%$
\end{tabular} \\
\hline
\end{tabular}

ing the flight in order to better adapt the loading of the meal on board or asking the passengers to deliver newspapers on board in order to make them available for other passengers and, therefore, reducing the amount of paper waste).

At this stage of the project, the anticipated reduction of GHG emissions has been estimated to be around $4,340 \mathrm{t} \mathrm{CO}_{2}$ eq. per year by using the LCA methodology. The functional unit chosen was the management of all the waste coming from the catering of Iberia aircrafts arriving in Madrid that were collected by Gate Gourmet and managed by Ferrovial during the year 2016. The burdens of the system, as Figure 3 shows, are the stages of unloading the waste from the Iberia aircrafts, transport to the GG facilities, collection of the waste by Ferrovial to take it to its selection plant, transport from Ferrovial to the different recyclers, recycling processes and the landfill. It also includes the savings associated with the production of electricity and primary secondary materials from alternative processes.

Gabi (2017) software was used for the calculations and the method of impact evaluation chosen was the one recommended by the ILCD Manual and those of the European Commission's Product Environmental Footprint Initiative, paying special attention to the environmental impact category of climate change to calculate the total carbon footprint.

The current situation has been compared with another scenario, in which Cat 1 recoverables and both Cat 1 and Cat3 organic matter being currently sent to landfill are managed with alternatives higher in the hierarchy: the recycling rates are 4.5 times higher and $88 \%$ of organic matter is considered to be sent to a valorization process from which biogas can be obtained as a sub-product.

\section{CONCLUSIONS}

Being in the early stages of the project, the preliminary outcomes are laying the groundwork for reaching the goals set. Through the state of the art analysis, we have been able to identify what the premises to be taken into account are when guiding future decisions through a life cycle perspective.

Using lighter aviation construction materials will reduce environmental impacts as a more efficient combustion will occur. Regarding catering food, menus with a greater amount of foods of vegetable origin will have a lower carbon footprint than those where there is the presence of meat, especially bovine.

LCA perspective should be taken into account when deciding what kind of material both for packaging and cutlery should be used, as the results depend on the number of uses of the reusable item, the efficiency of the washing 


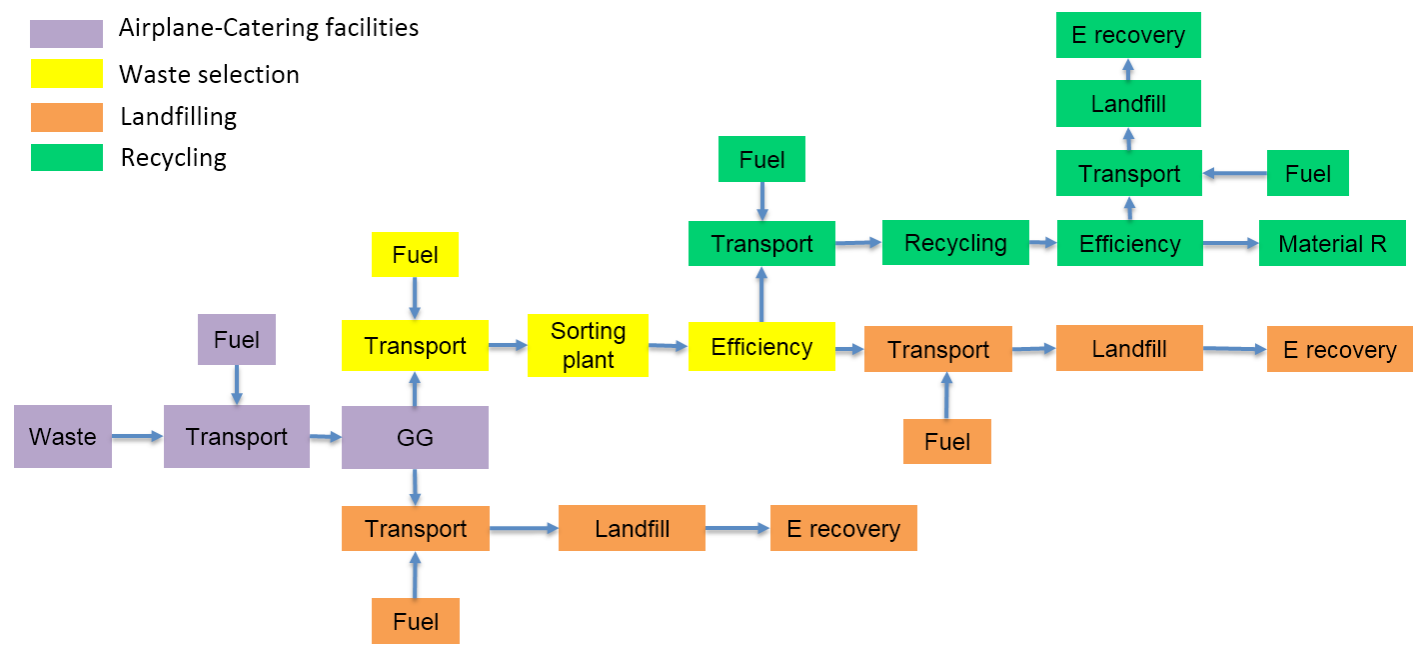

FIGURE 3: LCA stages for Cat3 and Cat1 waste management.

process and the number of washes between the uses since the washing stage is the one with the highest impact for the reusable items. In addition, single-use items fabrication has a less environmental impact and are lighter reducing emissions while flying.

In addition, the characterization study allows discover the composition of the waste and its origin, to plan an efficient and differentiated management. The outcomes of the study reveal that the distance of flight has a direct relationship between the amount of waste and the unmanipulated material generated. The majority of it, is organic matter that comes from the menus.

It is in the waste flow and in the tourist flows where most of the recoverable waste is, therefore more efforts have to be made there, for a correct separation in origin.

It is expected that with the development of the project and the implementation of measures in the current system, a substantial improvement of the entire process will be achieved. Moreover, if we take into account its more than probable replicability in other airports.

\section{ACKNOWLEDGEMENTS}

The authors are responsible for the choice and presentation of information contained in this paper as well as for the opinions expressed therein, which are not necessarily those of UNESCO and do not commit this Organization.

ZERO CABIN WASTE (LIFE/ENV/ES209) is co-financed by the European Union through the LIFE Programme. The project partners include Gate Gourmet Spain, ESCI-UPF Pompeu Fabra University, Biogas Fuel Cell, Iberia, Ecoembes and Ferrovial.

\section{REFERENCES}

ACI. (2017). Annual World Airport Traffic Report I ACI World. Retrieved from https://store.aci.aero/product/annual-world-airport-traffic-re port-2017/

Alaska Airways. (2015). Inflight waste - 2015 Sustainability Report Alaska Airlines. Retrieved March 22, 2018, from https://www.alaskaair.com/content/about-us/sustainability-report/environment/ inflight-waste
Beck, A. J., Hodzic, A., Soutis, C., \& Wilson, C. W. (2011). Influence of Implementation of Composite Materials in Civil Aircraft Industry on reduction of Environmental Pollution and Greenhouse Effect. Retrieved from http://iopscience.iop.org/1757-899X/26/1/012015

Bellarby, J., Foereid, B., Hastings, A., Smith, P., Pic, C. \& Beltrá, D. (2008). Cool Farming: Climate impacts of agriculture and mitigation potential. Retrieved from http://www.greenpeace.org/international/Global/international/planet-2/report/2008/1/cool-farmingfull-report.pdf

Bio Intelligence Service. (2010). Preparatory Study on food waste across EU 27. Paris. https://doi.org/10.2779/85947

Bogner, J., Abdelrafie Ahmed Sudan, M., Diaz, L., Kjeldsen, P., Monni, S., Gregory, R., ... Zhang, T. (2007). Waste Management, In Climate Change 2007: Mitigation. Contribution of Working Group III to the Fourth Assessment Report of the Intergovernmental Panel on Climate Change.

British Airways. (2018). Corporate Responsibility. Retrieved March 22, 2018, from https://www.britishairways.com/en-gb/information/ about-ba/csr/corporate-responsibility

Calabrò, P. S. (2009). Greenhouse gases emission from municipal waste management: The role of separate collection. Waste Management, 29(7), 2178-2187. https://doi.org/10.1016/j.wasman.2009.02.011

Calabrò, P. S., Gori, M., \& Lubello, C. (2015). European trends in greenhouse gases emissions from integrated solid waste management. Environmental Technology, 36(16), 2125-2137. https://doi.org/10 $.1080 / 09593330.2015 .1022230$

Cherubini, F., Bargigli, S., \& Ulgiati, S. (2009). Life cycle assessment (LCA) of waste management strategies: Landfilling, sorting plant and incineration. Energy, 34(12), 2116-2123. https://doi. org/10.1016/j.energy.2008.08.023

EC Packaging Waste Directive, E. C. (1994). European Parliament and Council Directive 94/62/EC of 20 December 1994 on packaging and packaging waste. Official Journal of the European Communities. https://doi.org/10.1093/jel/7.2.323

Eriksson, M., Strid, I., \& Hansson, -Anders. (2015). Carbon footprint of food waste management options in the waste hierarchy e a Swedish case study. Journal of Cleaner Production, 93, 115-125. https://doi.org/10.1016/j.jclepro.2015.01.026

EUROPEAN PARLIAMENT. (2009). REGULATION (EC) No 1069/2009 OF THE EUROPEAN PARLIAMENT AND OF THE COUNCIL of 21 October 2009. Retrieved from http://eur-lex.europa.eu/legal-content/EN/TXT/PDF/?uri=CELEX:32009R1069\&from=EN

Foster, C., Green, K., Bleda, M., \& Dewik, P. . (2007). Environmental impacts of food production and consumption: final report to the Department for Environment Food and Rural Affairs. Manchester Business School, University of Manchester.

Garrido, N., \& Alvarez del Castillo, M. D. (2007). Environmental evaluation of single-use and reusable cups. The International Journal of Life Cycle Assessment, 12(4), 252-256. https://doi.org/10.1065/ Ica2007.05.334 
Godson, J. (2014). Airline/Airport: Environmental Management Cooperation.3rd ACl Airport Environmental Seminar. Kuala Lumpur.

Horvath, A., \& Chester, M. V. (2008). Environmental Life-cycle Assessment of Passenger Transportation, (December). Retrieved from http://www.its.berkeley.edu/sites/default/files/publications/ UCB/2008/VWP/UCB-ITS-VWP-2008-2.pdf

Howe, S., Kolios, A. J., \& Brennan, F. P. (2013). Environmental life cycle assessment of commercial passenger jet airliners. Transportation Research Part D, 19, 34-41. https://doi.org/10.1016/j. trd.2012.12.004

Li, X. D., Poon, C. S., Lee, S. C., Chung, S. S., \& Luk, F. (2003). Waste reduction and recycling strategies for the in-flight services in the airline industry. Resources, Conservation and Recycling, 37(2), 87-99. https://doi.org/10.1016/S0921-3449(02)00074-5

Lopes, J. V. de O. F. (2010). Life Cycle Assessment of the Airbus A330-200 Aircraft. Assessment, 140. Retrieved from https://fenix. tecnico.ulisboa.pt/downloadFile/395142223995/Tese_JoaoVascoLopes.pdf

Official Journal of the European Union. (2008). DIRECTIVE 2008/98/ EC OF THE EUROPEAN PARLIAMENT AND OF THE COUNCIL of 19 November 2008 on waste and repealing certain Directives. Retrieved from http://eur-lex.europa.eu/legal-content/EN/TXT/ PDF/?uri=CELEX:32008L0098\&from=EN

Pro.mo/Unionplast. (2009). Comparative Life Cycle Assessment (Lca), 2(February), 69-75.
Sim, S., Barry, M., Clift, R., \& Cowell, S. J. (2007). The relative importance of transport in determining an appropriate sustainability strategy for food sourcing. The International Journal of Life Cycle Assessment, 12(6), 422-431. https://doi.org/10.1065/lca2006.07.259

Tassielli, G., Renzulli, P. A., Castellani, V., \& Sala, S. (2017). Environmental impacts of food consumption in Europe. Journal of Cleaner Production, 140, 753-765. https://doi.org/10.1016/j.jclepro.2016.06.080

Timmis, A. J., Hodzic, A., Koh, L., Bonner, M., Soutis, C., Schäfer, A. W., \& Dray, L. (2015). Environmental impact assessment of aviation emission reduction through the implementation of composite materials. The International Journal of Life Cycle Assessment, 20(2), 233-243. https://doi.org/10.1007/s11367-014-0824-0

Topham, G. (2018). Ryanair makes pledge to become "plastic free" on all flights by 2023 | Business | The Guardian. Retrieved March 22 2018, from https://www.theguardian.com/business/2018/jan/31/ ryanair-makes-pledge-plastic-free-all-flights-2023

Williams, A. G., Audsley, E., \& Sandars, D. L. (2006). Determining the environmental burdens and resource use in the production of agricultural and horticultural commodities. Retrieved from www. silsoe.cranfield.ac.uk,

Woods, L., \& Bakshi, B. R. (2014). Reusable vs. disposable cups revisited: guidance in life cycle comparisons addressing scenario, model, and parameter uncertainties for the US consumer. The International Journal of Life Cycle Assessment, 19(4), 931-940. https:// doi.org/10.1007/s11367-013-0697-7 